\title{
From embryonic tectonics and geosynclines to modern concepts of rifting, spreading, and Alpine orogenesis: a summary of contributions to the 9th Alpine Workshop (Cogne, 2009)
}

\author{
Mark R. Handy • Claudio L. Rosenberg
}

Received: 7 February 2011/Accepted: 11 February 2011/Published online: 18 March 2011

(C) Springer-Verlag 2011

The 9th Alpine Workshop was held in September of 2009 in the village of Cogne (Italy) amid, the spectacular geology and scenery of the Western Alps. This volume of the International Journal of Earth Science comprises a selection of papers read at the workshop, which in keeping with the workshop's tradition, encompassed a broad range of themes on the processes and evolution of Alpine-type mountain belts. The workshop itself was dedicated to the memory of Rudolph Trümpy (1921-2009), a key figure in Alpine Geology and a frequent participant of past Alpine workshops. The keynote paper by Sengör and Bernoulli reviews Trümpy's scientific oevre in the context of his time, especially his landmark paleogeographic reconstructions of Alpine Tethys and his early recognition of the role of strike-slip tectonics in the evolution of the Alps. Beyond these contributions, their paper provides insight into how Trümpy inspired colleagues and students alike to look carefully at rocks and to think critically about the geologic record, even as he acknowledged the need for a deductive approach to further our understanding of orogenesis.

One of Trümpy's many insights was that Alpine Tethys resulted from Mesozoic extension (rather than shortening) and that the structure of the adjacent European and Adriatic continental margins did not coincide with the impressive nappe structures that formed later during Alpine subduction and collision. It is therefore fitting that several papers in this volume deal with this early evolution and its effect on Alpine orogenic structure. Mohn, Manatschal, Massini, and Müntener present a revised interpretation of Austroalpine units that represent the distal Adriatic continental

M. R. Handy · C. L. Rosenberg ( $\square)$

Freie Universität Berlin, Berlin, Germany

e-mail: cla@zedat.fu-berlin.de margin as preserved at the junction of Eastern and Central/ Western Alps in eastern Switzerland. In a series of E-W oriented palinspastic reconstructions, the authors show how Early Mesozoic rift-related structures of this margin determined the complex sequence of nappe stacking during late Cretaceous east-west shortening. Further complications arose during Tertiary north-south shortening, yet the original pre-orogenic structure of the passive margin is shown to be remarkably well preserved.

In the Western Alps, Loprieno, Bousquet, Bucher, Ceriani, Fügenschuh, and Schmid present new structural and stratigraphic evidence for the existence of Valais oceanic lithosphere in Cretaceous time. Internal Valais units (Versoyen ophiolites and underlying magmatic and sedimentary rocks) are shown to have originated at the ocean-continent transition in contrast with external Valais units that did not have an oceanic lithosphere and probably derived from the European distal continental margin. This interpretation will be controversial to some Alpine geologists, as it refutes previous interpretations of the "Versoyen ophiolites" as a Carboniferous-age complex in tectonic (rather than stratigraphic) contact with post-rift sediments of the internal Valais unit.

The Early Mesozoic paleogeography of the eastern part of the European margin of Alpine Tethys has been relatively poorly constrained until now. By careful dating of pre-Mesozoic basement rocks in the western part of the Tauern Window, Vesela, Sölner, Finger, and Gerdes correlate the sub-Penninic "Zentral Gneiss" there with the External basement Massifs in the Western Alps of Switzerland and France. Synsedimentary rhyodacitic and rhyolitic horizons (310-304 Ma) in these units along the Alpine chain are interpreted to mark the onset of sedimentation in a post-Variscan extensional basins, just prior to the onset of Early Perman intracontinental rifting. 
Alpine subduction and its transition to collision in Early Cenozoic time continues to be an attractive topic, possibly reflecting the fact that so much work remains to be done, and that overprinting of most direct traces of subduction presents a major challenge. The metamorphic manifestation of this transition is preserved along the periphery of the Lepontine thermal dome in the basement core of the Central Alps, where Wiederkehr, Bousquet, Ziemann, Berger, and Schmid employ state-of-the-art geothermometry in metasediments to map the three-dimensional shape of isotemperature contours associated with regional metamorphism. The interference pattern of the contours clearly documents overprinting of Early Tertiary high-pressure "subduction" metamorphism by later Tertiary high-temperature metamorphism as well as post-Late Eocene displacement.

To the west around the Alpine arc, in the northern Dora Maira unit (Western Alps), Gasco, Gattiglio, and Borghi relate the structural evolution to the history of subduction and subsequent exhumation. They show that the main foliation developed under retrograde conditions during topto-the-west (foreland-directed) shearing and isoclinal folding of the thrust contact between Piedmont (LigurianPiedmont ocean) and Dora Maira units (European-derived basement). Thus, these units were juxtaposed after subduction to peak baric conditions but before shearing and final emplacement under greenschist-facies conditions. The clockwise pressure-temperature path for the northern Dora Maira unit confirms previous work indicating that the rocks of this unit underwent near-isothermal decompression after attainment of the baric peak and did not experience a late temperature increase.

Where field relations are complex and/or not well know due to the dearth of field-based studies, modelers attempt to fill the gap. Carry, Gueydan, Marquer, and Brun extract thermobarometric information from exhumed units of formerly subducted European margin as input information for two-dimensional thermomechanical modeling of Early Cenozoic Alpine subduction. They infer that the dip of the European slab may have increased from east to west along strike of the Alpine active margin during Eocene to Oligocene time. In part, this reflects changes in the buoyancy of the slab associated with the nature of the incoming lithosphere (oceanic vs. continental).

A vexing problem in Alpine geology has been the response of the upper (Adriatic) plate to Early Cenzoic subduction. Did it shorten and, if so, when and by how much? D'Adda, Zanchi, Bergomi, Berra, Malusà, Tunsei, and Zanchetta provide new evidence that there was indeed some north-south shortening, although the amount remains unknown. Magmatic dykes and other bodies emplaced at very shallow levels at $42-39 \mathrm{Ma}$ (U-Pb zircon) truncate imbricates of the south-directed Orobic thrust in the
Southern Alps, corroborating previous interpretations that at least some of the north-south shortening was older than the intrusion of the Adamello batholith. Moreover, the dyke intrusions were coincident with minor NW-SEdirected extensional faulting, betraying a local syn-magmatic extensional regime that has not been described previously in this area. The shallow level of the intrusions suggests that no significant post-Eocene exhumation affected the northern part of the Southern Alps.

The surface manifestation of the transition from subduction to collision has been a matter of contention for some time, with opinions depending on the criteria (e.g., age of Periadriatic magmatism, onset of rapid sedimentation in the Molasse basin) used to mark this transition. In the inner arc of the Western Alps, Kapferer, Mercolli, and Berger identify a steeply SE-dipping Oligocene regolith that stratigraphically overlies both the Late Cretaceous high-pressure metamorphic rocks of the Sesia-Lanzo Zone (NW Italy) and the base of the Oligocene Biella volcanic suite. Alteration minerals in the regolith are interpreted as evidence for reburial. Together with its substrate and volcanic cover, the regolith is inferred to have attained its present steep orientation sometime between Late Eocene and Early Oligocene time. The authors do not speculate on the possible causes of this tilting, but an obvious candidate would be incipient activity of the Periadriatic (Insubric) Line during the onset of Alpine collision.

The construction of a new cross-section along the classical Brenner transect in the Eastern Alps enables Rosenberg and Garcia to estimate the amount of syn-orogenic displacement associated with extensional faulting and folding. They propose that exhumation of the Penninic units in the Tauern Window was accommodated mainly by crustal-scale folding and erosion, and that normal faulting along the Brenner Line played only a subordinate role. This raises the interesting possibility that tectonic denudation by orogen-parallel extension has been overestimated in past interpretations of Miocene indentation tectonics in the Eastern Alps.

Surface processes were yet another controversial theme at the workshop insomuch as debate currently waged in the literature focusses on the possibility that erosion, possibly coincident with climate change, has driven uplift of the Alps. In a synoptic overview of the northern Alpine foreland (Molasse) basin, Schlunegger and Mosar argue that Miocene erosion of this basin occurred in response to a tectonically induced shift in the drainage direction rather than to a change in paleoclimate. Climate left an imprint on the Alpine landscape, but presumably not before the beginning of glaciation at the Pliocene-Pleistocene boundary. They conclude with a plea for more careful consideration of both tectonic and climatic forcing on the development of the Alps and the adjacent Molasse Basin. 
Norton, von Blanckenburg, DiBiase, Schlunegger, and Kubik summarize new basin-averaged denudation rates from cosmogenic ${ }^{10} \mathrm{Be}$ measured in quartz from large Alpine rivers. They invoke geomorphic inheritance as a major factor controlling erosion, such that large erosive glaciers in the late Quaternary cold periods were more effective in priming landscapes in the Central Alps for erosion than in the interior Eastern Alps. However, the differing geomorphic responses of the Eastern and Central Alps may also reflect accretion in the east due to counterclockwise rotation of the Adriatic indenter about a pole located somewhere in the western part of the Southern Alps or Po Basin.

No Alpine Workshop held so far has been confined solely to contributions from the Alps themselves, so it was no surprise that some papers read at the Cogne workshop pertained to adjoining segments of the Alpine chain. Schefer, Cvetkovic, Fügenschuh, Kounov, Ovtcharova, Schalegger, and Schmid showed that granitic plutons of the internal Dinarides (southern Serbia) were emplaced in Late Oligocene (31.7-30.6 Ma) and Early Miocene (20-18 Ma) time before undergoing rapid exhumation by extensional unroofing between 16 and $10 \mathrm{Ma}$. They further propose delamination of the Adriatic mantle after final closure of the Neotethys in Eocene time to explain the evolution from Cretaceous magmatism in the upper (European) plate to Tertiary magmatism in the lower (Adriatic) plate. This magmatism contrasts with Miocene granites in metamorphic core complexes of the Internal Dinarides that may have formed during back-arc extension above the westward- diping European slab that retreated to the east to its present location beneath the Carpathian fold belt.

The Alpine eological community has always benefitted from a look at younger orogens, particularly where ongoing subduction and collision provide a view of processes that are no longer active in the Alps. Comparing the Western Alps-Apennine system with the active Taiwan orogen, Molli and Malavielle point out that both orogens experienced a change in subduction polarity associated with slabbreakoff and opening of a back-arc basin that propagated into part of the orogen. Inspired by the Taiwan orogen, the authors propose that the European plate in the Western Alps-Apennine system initially subducted to the southeast in Late Cretaceous-Early Middle Miocene time, but detached once Corsican continental crust entered the subduction zone. This facilitated a change in subduction polarity to westward "Apenninic" subduction of the Adriatic plate in Late Eocene-Oligocene time. We note that this "two subduction" model and previously published variations thereof contrast with "single" subduction models involving continuous northwest subduction of the Adriatic plate (includes the Ligurian part of Alpine Tethys) since Late Cretaceous time. Controversy on this issue is guaranteed to continue!

At the time of writing, the next Alpine Workshop in Corsica (April 10-16, 2011) is almost upon us. We want to thank the many colleagues who took time to review these manuscripts, sometimes more than once, and the chief editor, Christian Dullo, for ensuring that the publication schedule announced at the workshop was indeed realized. 